\title{
Correlation Coefficient Analysis for Yield and its Components in Joha Rice (Oryza sativa L.) Genotypes of Assam in Response to Organic and Inorganic Condition
}

\author{
Khirud Panging ${ }^{1}{ }^{*}$, Debojit Sarma ${ }^{1}$, Rumjhum Goswami Phukon ${ }^{1}$ and Larbeen Teronpi ${ }^{2}$ \\ ${ }^{1}$ Department of Plant Breeding and Genetics, Jorhat, Assam, India \\ ${ }^{2}$ Department of Crop Physiology, Assam Agricultural University, Jorhat, Assam, India \\ *Corresponding author
}

\begin{abstract}
A B S T R A C T
Twelve genotypes of rice (Oryza sativa L.) were evaluated during Kharif 2015 to study the nature and extent of correlation among yield and yield attributing characters, number of tillers per plant, plant height, panicle length, number of grains per panicle, 1000-grain weight, days to first flowering, days to 50 per cent flowering, days to maturity, grain yield per plant. In organic environment condition, it was recorded that yield attributing character such as effective tiller number (0.3972) shows significant phenotypic positive correlation coefficient with the grain yield per plant. While grains per panicle (-0.3774) shows negatively significant correlation with the grain yield per plant at phenotypic level. In case of inorganic panicle length (0.5429), days to first flowering (0.4412), thousand grain weight (0.4327) and days to 50\% flowering shows phenotypically positive correlation with grain yield per plant. Character association studies revealed that the characters grain yield per plant showed significant positive association with plant height, 1000 grain weight. This indicated that simultaneous selection of all these characters was important for yield improvement.
\end{abstract}

Keywords

Correlation,

Yield, Character, Genotypes

Article Info

Accepted:

22 October 2020

Available Online:

10 November 2020

\section{Introduction}

Rice is one of the important cereal crops of the world. It is the main cultivated crop in India as well as in Assam. In Assam, a large number of indigenous rice cultivars are grown by the farmers and a number of such cultivars have been genetically improved through breeding programmes. Assam, being one of the centres of diversity of rice, harbours very rich genetic resources for different traits of importance for immediate utility as well as for the future. Joha rice is a one of the rice classes which is mostly grown in Assam. This class of rice enjoys a unique position in terms of popularity. The Joha rice cultivars are known for its strong aroma, fine grain, good cooking qualities and excellent palatability 
(Das et al., 2010). A global market for Joha rice from Assam is heading the way with its entry into the European market in 2007. Efforts are on to obtain Geographical Indication tag for the fragrant non-basmati Joha rice of Assam.

It is high time to focus on its cultivation under organic farming for maintaining its unique quality and also to identify desirable traits for breeding high yielding varieties suitable for organic farming. Crop yield is the end product of the interaction of a number of other interrelated attributes. A thorough understanding of the interaction of characters among themselves had been of great use in plant breeding. The efficiency of selection for yield mainly depends on the direction and magnitude of association between yield and its component characters and also among themselves.

Character association provides information on the nature and extent of association between pairs of metric traits and helps in selection for the improvement of the character. For the improvement of grain yield, the knowledge on the association between grain yield and its component characters will be helpful.

In general, genotypic correlations were found to be higher than phenotypic correlations, which indicate that though there is strong inherent association between characters studies, its expression is lessened due to influence of environment and considering the importance of phenotypic correlation

\section{Materials and Methods}

The experiment comprised of Twelve diverse Joha genotypes of rice comprising 10 indigenous cultivars and two developed varieties. The experiment was carried out at ICR farm, Jorhat Assam Agricultural University during kharif 2015. The experiment was conducted under inorganic and organic condition. The site was located at $26^{\circ} 45^{\prime}$ north latitude and $94^{\circ} 12^{\prime}$ east longitude having an elevation of $87 \mathrm{~m}$ above the mean sea level. The genotypes included in the present investigation consisted of two improved varieties and ten indigenous Joha rice cultivars of the Assam. The pedigree, origin and source of the genotypes are presented in Table 1. The genotypes were investigated in two different growing conditions - inorganic and organic culture. The aim of the experiment was to find out the yield and yield attributes characters relationships in response to organic and inorganic in condition. The experimental trial was laid out in Randomized Complete Block design with three replications under inorganic and organic environment conditions. Each genotype per replication was allotted a gross plot of size $3 \mathrm{~m} \times 1.8 \mathrm{~m}$ ( 9 rows of $3 \mathrm{~m}$ ). Two seedling was planted per hill with a spacing of $20 \times 15 \mathrm{~cm}$. Data on the basis of 5 randomly taken competitive plants excluding borders were recorded on days to first flowering, days to $50 \%$ flowering, days to maturity, plant height $(\mathrm{cm})$, effective tiller, panicle length $(\mathrm{cm})$, panicle weight $(\mathrm{g})$, grains per panicle, thousand grain weight $(\mathrm{g})$ and grain yield per plant $(\mathrm{g})$. The correlation coefficients among various characters were calculated at genotypic and phenotypic level using the formulae given by Al-Jibouri et al., (1985). Soil analysis was done before layout of the experiment and after harvest. Representative samples of soil were collected from a depth of $20-25 \mathrm{~cm}$. For preparation of soil samples the method for soil sampling was adopted from Jackson (1973). Soil samples were taken from different points of the experimental field and, thereafter, composited. The results of the analyses are given in Appendix I.

\section{Results and Discussion}

Information on both genotypic and phenotypic correlation coefficient is important in selection programme. Only when 
characters have high heritability, the genetic correlation assumes importance. Otherwise, environmental correlation is the chief determinant of the phenotypic correlation. Thus the magnitude and even the direction of the genetic correlation cannot be determined from the phenotypic correlation alone. Moreover, grain yield is a complex character governed mostly by polygenes and it is the resultant expression of several interrelated characters, thus it is imperative to obtain information on the characters which influence grain yield. This will help in formulating suitable selection criteria for the indirect selection of grain yield.

In organic environment condition, it was recorded that yield attributing character such as effective tiller number (0.3972) shows significant phenotypic positive correlation coefficient with the grain yield per plant. While grains per panicle (-0.3774) shows negatively significant correlation with the grain yield per plant at phenotypic level. Characters, days to first flowering (0.2586), days to $50 \%$ flowering (0.2844), days to maturity (0.3171), plant height (0.1124), panicle length (0.214), panicle weight (0.0682) and thousand grain weight shows phenotypically positive correlation with the grain yield per plant. While in case of genotypic correlation coefficient, character grain panicle weight per plant $(-0.0952)$ and thousand grain weight $(-0.5365)$ were shows negatively correlation coefficient with grain yield per plant. While other characters effective tiller (0.9403), panicle length (0.8535), days to maturity (0.4509), thousand grain weight (0.3556), days to $50 \%$ flowering (0.3181), days to first flowering (0.2726) and plant height $(0.1382)$ were shows positively correlated with the grain yield per plant. Similar results were reported by Idris et al., (2013) for effective tiller per plant, Satish Chandra et al., (2009), Basavaraja et al., (2011), Patel et al., (2014), Rao et al., (2014) for 1000 grain weight, with grain yield per plant. Characters and shows higher correlation coefficient value than others with the grain yield per plant it means the two characters highly effective with the yield of the plant. Hence, these characters could be considered as criteria for selection for higher yield as these were mutually and directly associated with grain yield (Table 2).

In inorganic condition it was revealed that most of the characters were phenotypically significant correlated with gain yield per plant as compare with organic culture. Panicle length (0.5429), days to first flowering (0.4412), thousand grain weight $(0.4327)$ and days to $50 \%$ flowering shows phenotypically positive correlation with grain yield per plant. Similar results were reported by Satish Chandra et al., (2009), Basavaraja et al., (2011), Patel et al., (2014), Rao et al., (2014) for 1000 grain weight. Characters effective tiller per plant (-0.3891) and grains per panicle (-0.4246) were shows significant negatively correlated with grain yield per plant. In case of genotypic correlation coefficient, grains per panicle (-0.8872), effective tiller per plant $(-0.4435)$ and plant height (-0.0682) were recorded negatively correlated with grain yield per plant. In both cases the two character grains per panicle and effective tiller per plant shows negative relationships with the grain yield per plant. From these result we can concluded that there is a room of improvement in case of these two characters that can leads to the increasing of yield of the plant.

In conclusion, character association studies revealed that the characters grain yield per plant showed significant positive association with effective tillers per plant in organic condition. While in inorganic condition characters days to first flowering, days to $50 \%$ flowering, panicle length and 1000 grain weight showed significant positive 
association with grain yield per plant. This indicated that simultaneous selection of all these characters was important for yield improvement (Table 3).

Table.1 Details of rice genotypes used in the experiment

\begin{tabular}{|l|l|l|l|l|}
\hline $\begin{array}{l}\text { Entry } \\
\text { No. }\end{array}$ & $\begin{array}{l}\text { Name of the } \\
\text { entry }\end{array}$ & Pedigree & Origin & Source \\
\hline V1 & Keteki Joha & Sabitri/Badshabhog & Assam & ICR Farm, AAU, Jorhat \\
\hline V2 & Bokul Joha & Sabitri/Badshabhog & Assam & ICR Farm, AAU, Jorhat \\
\hline V3 & Kon Joha & Indigenous & Assam & ICR Farm, AAU, Jorhat \\
\hline V4 & Kunkuni Joha & Indigenous & Assam & RARS, Karimganj \\
\hline V5 & Local Joha & Indigenous & Assam & ICR Farm, AAU, Jorhat \\
\hline V6 & $\begin{array}{c}\text { Kukrajhar local } \\
\text { Joha }\end{array}$ & Indigenous & Assam & $\begin{array}{l}\text { Deptt. of Agronomy, AAU, } \\
\text { Jorhat }\end{array}$ \\
\hline V7 & Kali Jeera & Indigenous & Assam & RARS, Karimganj \\
\hline V8 & Harinarayan & Indigenous & Assam & Deptt. of PBG, AAU,Jorhat \\
\hline V9 & Jawalpool & Indigenous & Assam & RARS, Karimganj \\
\hline V10 & Manimuni Joha & Indigenous & Assam & RARS, Karimganj \\
\hline V11 & Indrabhog & Indigenous & Assam & Deptt. of PBG, AAU,Jorhat \\
\hline V12 & Kola Joha & Indigenous & Assam & ICR Farm, AAU, Jorhat \\
\hline
\end{tabular}

Table.2 Genotypic (above diagonal) and phenotypic (below diagonal) correlation coefficients for yield attributes traits of 12 Joha rice genotypes under organic condition

\begin{tabular}{|c|c|c|c|c|c|c|c|c|c|c|}
\hline $\begin{array}{c}\text { Charac } \\
\text { ter }\end{array}$ & $\begin{array}{c}\text { Days to } \\
\text { first } \\
\text { flowering } \\
\text { (DF) }\end{array}$ & $\begin{array}{c}\text { Days to } \\
50 \% \\
\text { flowering } \\
\text { (DFF) }\end{array}$ & $\begin{array}{l}\text { Days to } \\
\text { maturity } \\
\text { (DM) }\end{array}$ & $\begin{array}{c}\begin{array}{c}\text { Plant } \\
\text { height } \\
(\mathbf{c m}) \\
{[\mathrm{PH}]}\end{array}\end{array}$ & $\begin{array}{l}\text { Effective } \\
\text { tiller (ET) }\end{array}$ & $\begin{array}{c}\text { Panicle } \\
\text { length } \\
\text { (cm) } \\
{[\mathrm{PL}]}\end{array}$ & $\begin{array}{l}\text { Panicle } \\
\text { weight } \\
\text { (g) }[\text { PW] }\end{array}$ & $\begin{array}{c}\text { Grains per } \\
\text { panicle } \\
\text { (GPP) }\end{array}$ & $\begin{array}{c}\text { Thousan } \\
\text { d grain } \\
\text { weight } \\
(\text { g) } \\
\text { [TGW] }\end{array}$ & $\begin{array}{c}\text { Grain } \\
\text { yield per } \\
\text { plant (g) } \\
{[\text { GYP] }}\end{array}$ \\
\hline DF & & 1.0027 & 0.8365 & -0.1102 & 1.0002 & -0.1119 & -0.7178 & -0.4823 & 0.3256 & 0.2726 \\
\hline DFF & $\begin{array}{l}0.9755 \\
* * *\end{array}$ & & 0.8404 & -0.1186 & 0.945 & -0.0386 & -0.6985 & -0.5163 & 0.3565 & 0.3181 \\
\hline DM & $\begin{array}{c}0.6056 \\
* * *\end{array}$ & $\begin{array}{c}0.6850 \\
* * *\end{array}$ & & -0.4414 & 0.943 & 0.3161 & -0.3604 & -0.5179 & 0.8473 & 0.4509 \\
\hline PH & -0.098 & -0.1172 & -0.3121 & & -0.4405 & 0.0779 & 0.256 & 0.076 & -0.3523 & 0.1382 \\
\hline ET & 0.315 & $0.3738 *$ & $\begin{array}{c}0.4485 \\
* *\end{array}$ & -0.2137 & & 0.9693 & -0.6656 & -1.207 & 0.5661 & 0.9403 \\
\hline PL & 0.0094 & -0.0045 & 0.1495 & 0.0141 & 0.1735 & & 0.1053 & -0.9807 & 0.7275 & 0.8535 \\
\hline PW & $\begin{array}{c}-0.4983 \\
* *\end{array}$ & $\begin{array}{c}-0.4766 \\
* *\end{array}$ & -0.1851 & 0.2023 & -0.2218 & 0.2227 & & 0.4035 & 0.0127 & -0.0952 \\
\hline GPP & $-0.3903 *$ & $\begin{array}{c}-0.4313 \\
* *\end{array}$ & -0.2851 & 0.1088 & $-0.4244 * *$ & -0.0415 & $\begin{array}{c}0.4613 \\
* *\end{array}$ & & -0.3888 & -0.5365 \\
\hline TGW & $0.3292 *$ & $0.3470 *$ & $\begin{array}{l}0.5930 \\
* * *\end{array}$ & $\begin{array}{c}- \\
0.3306 \\
*\end{array}$ & 0.2118 & 0.2716 & 0.0015 & $-0.3411 *$ & & 0.3556 \\
\hline GYP & 0.2586 & 0.2844 & 0.3171 & 0.1124 & $0.3972 *$ & 0.214 & 0.0682 & $-0.3774 *$ & 0.3267 & \\
\hline
\end{tabular}


Table.3 Genotypic (above diagonal) and phenotypic (below diagonal) correlation coefficients for yield attributes traits of 12 Joha rice genotypes under inorganic condition

\begin{tabular}{|c|c|c|c|c|c|c|c|c|c|c|}
\hline Character & $\begin{array}{l}\text { Days to first } \\
\text { flowering } \\
\text { (DF) }\end{array}$ & $\begin{array}{l}\text { Days to 50\% } \\
\text { flowering } \\
\text { (DFF) }\end{array}$ & $\begin{array}{l}\text { Days to } \\
\text { maturity } \\
\text { (DM) }\end{array}$ & $\begin{array}{c}\text { Plant } \\
\text { height } \\
(\mathrm{cm})[\mathrm{PH}]\end{array}$ & $\begin{array}{l}\text { Effective } \\
\text { tiller (ET) }\end{array}$ & $\begin{array}{c}\text { Panicle } \\
\text { length }(\mathrm{cm}) \\
{[\mathrm{PL}]}\end{array}$ & $\begin{array}{c}\text { Panicle } \\
\text { weight } \\
\text { (g) } \\
{[\mathrm{PW}]}\end{array}$ & $\begin{array}{l}\text { Grains per } \\
\text { panicle } \\
\text { (GPP) }\end{array}$ & $\begin{array}{l}\text { Thousand } \\
\text { grain } \\
\text { weight (g) } \\
\text { [TGW] }\end{array}$ & $\begin{array}{c}\text { Grain } \\
\text { yield per } \\
\text { plant (g) } \\
\text { [GYP] }\end{array}$ \\
\hline DF & & 0.9839 & 0.8872 & 0.0053 & -0.4238 & 0.8208 & 0.0101 & -0.441 & 0.2283 & 0.5602 \\
\hline DFF & $0.9526 * * *$ & & 0.932 & 0.1165 & -0.3844 & 0.5478 & -0.1322 & -0.4199 & 0.1861 & 0.4494 \\
\hline DM & 0.8500 *** & $0.9081 * * *$ & & 0.2364 & -0.4811 & 0.3235 & -0.3464 & -0.4579 & 0.0763 & 0.313 \\
\hline PH & 0.029 & 0.1148 & 0.2205 & & -0.4254 & -0.5692 & -0.1479 & 0.3328 & -0.4231 & -0.0682 \\
\hline ET & -0.3246 & $-0.3469 *$ & $-0.4179 *$ & $-0.3402 *$ & & -0.1869 & 0.1513 & 0.216 & 0.2587 & -0.4435 \\
\hline PL & $0.3881 *$ & 0.2711 & 0.1342 & -0.2602 & -0.1265 & & 0.8126 & -0.6686 & 0.6168 & 0.8796 \\
\hline PW & 0.0491 & -0.1064 & -0.3 & -0.1652 & 0.1651 & $0.5557 * * *$ & & 0.1778 & -0.0408 & 0.1966 \\
\hline GPP & $-0.3321 *$ & -0.325 & $-0.3439 *$ & 0.2196 & 0.1888 & -0.0233 & 0.2502 & & -0.5212 & -0.8872 \\
\hline TGW & 0.2193 & 0.1765 & 0.0778 & $-0.3890 *$ & 0.2371 & $0.3341 *$ & 0.0004 & $-0.4371 * *$ & & 0.5712 \\
\hline GYP & $0.4412 * *$ & $0.3871 *$ & 0.2579 & -0.0657 & $-0.3897 *$ & $0.5429 * * *$ & 0.3007 & $-0.4246 * *$ & $0.4327 * *$ & \\
\hline
\end{tabular}

Annexure - I

Soil characteristics of the experimental sites

\section{A. Chemical properties of the soil}

\begin{tabular}{|c|c|c|c|c|c|}
\hline \multicolumn{3}{|c|}{ Organic culture } & \multicolumn{2}{|c|}{ Initial (before planting) } & \multicolumn{2}{c|}{ After harvesting } \\
\hline Sl. No. & Characteristics & Value & Inference & Value & \\
\hline $\mathbf{1}$ & $\mathrm{pH}$ & 5.26 & Acidic & 5.35 & Acidic \\
\hline $\mathbf{2}$ & Available N (Kg/ha) & 277.39 & Medium & 309.25 & Medium \\
\hline $\mathbf{3}$ & Available P (Kg/ha) & 26.58 & Medium & 40.04 & Medium \\
\hline $\mathbf{4}$ & Available K (Kg/ha) & 125.26 & Low & 158.05 & Low \\
\hline \multicolumn{7}{|c|}{ Inorganic culture } \\
\hline $\mathbf{1}$ & pH & 4.8 & Acidic & 4.96 & Acidic \\
\hline $\mathbf{2}$ & Available N (Kg/ha) & 297.87 & Medium & 254.31 & Medium \\
\hline $\mathbf{3}$ & Available P (Kg/ha) & 21.28 & Medium & 20.63 & Medium \\
\hline $\mathbf{4}$ & Available K (Kg/ha) & 101.71 & Low & 114.54 & Low \\
\hline
\end{tabular}

\section{B. Microbial properties of the soil}

\begin{tabular}{|c|c|c|c|}
\hline \multicolumn{2}{|c|}{ Organic culture } & Initial (before planting) & After harvesting \\
\hline Sl. No. & Characteristics & Value & Value \\
\hline 1 & Microbial biomass carbon $(\mu \mathrm{g} / \mathrm{g} /$ dry soil $)$ & 869.6 & 966.97 \\
\hline 2 & Dehydrogenage activity ( $\mu$ g TPF/g/day) & 37.59 & 75.29 \\
\hline 3 & Phosphomonoesterase activity ( $\mu \mathrm{g} \mathrm{PNP} / \mathrm{g} / \mathrm{hr}$ ) & 33.86 & 64.21 \\
\hline \multicolumn{4}{|c|}{ Inorganic culture } \\
\hline 1 & Microbial biomass carbon $(\mu \mathrm{g} / \mathrm{g} /$ dry soil) & 124 & 132 \\
\hline 2 & Dehydrogenage activity ( $\mu$ g TPF/g/day) & 13.66 & 19.8 \\
\hline 3 & Phosphomonoesterase activity ( $\mu \mathrm{g} \mathrm{PNP} / \mathrm{g} / \mathrm{hr}$ ) & 22.94 & 31.97 \\
\hline
\end{tabular}

Source: Deptt. of Soil Science, Assam Agricultural University, Jorhat 
A critical analysis of correlation indicated that emphasis should be directed towards selection of parents having longer panicle length per plant coupled with higher 1000 grain weight. As the yield component, grains per panicle are intern dependent on panicle length and plant height, attention should be paid towards increasing the panicle length, maintaining optimum plant height. Thus, a plant with medium height with increased panicle length, higher number of grains per panicle and productive tillers per plant would be more desirable for selection to realize higher yield.

\section{References}

Al-jibouri, N.A.; Miller, P.A. and Robinson, H.P. (1985). Genotypic and environmental variances, Co-variance in an upland cotton cross of interspecific origin. Agron. J. 50: 633637.

Basavaraja, T., Gangaprasad, S., Dhusyantha Kumar, B. M and Shilaja Hittlamani. 2011. Correlation and path analysis of yield and yield attributes in local rice cultivars (Oryza sativa L.). Electronic J. Plant Breeding, 2(4): 523-526.

Das, A.; Tushar; Kesari, V. and Rangan, L.
(2010). Aromatic joha rice of Assama review. Agric. Rev. 31 (1): 1-10.

Idris, A.E. and Mohammed, K.A. 2013. estimation of genetic variability and correlation for grain yield components in rice (Oryza sativa L.) Global $J$. Plant Ecophysiol., 3(1): 1-6.

Jackson, M.L., (1973). Soil chemical analysis, Prentice Hall of India Private Limited, 1st edition, New Delhi, India. .

Patel, J.R., Saiyad, M.R., Prajapati, K.N., Patel, R.A and Bhavani R.T. 2014. Genetic variability and character association studies in rainfed upland rice (Oryza sativa L.) Electronic J. Plant Breeding, 5(3): 531-537.

Rao, V.T., Mohan, Y.C., Bhadru, D., Bharathi, D and Venkanna, V. 2014. Genetic variability and association analysis in rice. Int. J. Appl. Biol. Pharmaceutical Technol., vol. 5, issue 2.

Satish Chandra, B., Dayakar Reddy, T., Ansari, N.A. and Sudheer Kumar, S. 2009. Correlation and path analysis for yield and yield components in rice (Oryza sativa L.) Agri. Sci. Digest, 29(1): 45-47.

\section{How to cite this article:}

Khirud Panging, Debojit Sarma, Rumjhum Goswami Phukon and Larbeen Teronpi. 2020. Correlation Coefficient Analysis for Yield and its Components in Joha Rice (Oryza sativa L.) Genotypes of Assam in Response to Organic and Inorganic Condition. Int.J.Curr.Microbiol.App.Sci. 9(11): 3057-3062. doi: https://doi.org/10.20546/ijcmas.2020.911.371 